(REVIEW ARTICLE)

\title{
Challenges of the intensive insulin therapy in experimental models of extensive burn injury
}

Hananiah Tardivo Quintana ${ }^{1,}{ }^{*}$, Vivianne Izabelle de Araújo Baptista ${ }^{2}$, Mariana Cruz Lazzarin ${ }^{1}$ and Flavia de Oliveira $^{1}$

\author{
1 Department of Biosciences, Federal University of São Paulo, UNIFESP, SP, Brazil. \\ ${ }^{2}$ Multicampi School of Medical Sciences of the Rio Grande do Norte, Federal University of the Rio Grande do Norte, RN, \\ Brazil.
}

Publication history: Received on 23 July 2020; revised on 03 August 2020; accepted on 06 August 2020

Article DOI: https://doi.org/10.30574/wjarr.2020.7.2.0277

\begin{abstract}
Burn injuries (BI) above $40 \%$ of total body surface area (TBSA) are considered extensive and associated to systemic responses. The intensive insulin therapy (IIT) has been chosen as treatment because of its anabolic and antiinflammatory properties, and by glycemic control. Several experimental models of extensive BI with IIT has just been studied, however they have many variables and challenges. Thus, this review aims to investigate the animal models of extensive BI with IIT, in order to better understanding benefits and limitations of this therapy. The review of papers published on the literature and indexed on the PubMed database was conducted by searching the keywords predetermined. Insulin administration after BI is able to revert hyperglycemia state, accelerate wound healing, decrease the mRNA expression of some pro-inflammatory cytokines, attenuate acute lung injuries, decrease inflammation in intestinal epithelium and attenuate the muscle loss. We can conclude, although there are limitations related to burn standard or insulin administration, the systemic benefits of ITT overcome limitations.
\end{abstract}

Keywords: Burn; Insulin; Metabolism; Intensive insulin therapy; Insulin resistance.

\section{Introduction}

Burns injuries (BI) are highly debilitating traumas, causing about 265,000 deaths per year in the world [1]. In Brazil occurred an average 25,000 hospitalizations for burns and corrosion between 2010 until 2015, which generated high government spending [2]. Extensive BI have great relevance especially in children, being scalding case the most common, principally in domestic environments [3].

Burns covering more than 30\% total body surface area (TBSA) are associated to intense stress, inflammation and hypermetabolism, with consequent insulin resistance (IR) and hyperglycemia. These symptoms can affect the healing of the wound and causes development delay and other complications for about to 2 years. Furthermore, predisposes to complication various, as severe and fatal infections $[4,5]$.

The main severe response of BI is the hypermetabolic state and protein losses, which resulted of increased protein degradation more than synthesis, and the second major response is hyperglycemia state [6]. Thus, several treatments have been used for glycemic control, such as insulin because of its anabolic and anti-inflammatory properties [7].

Despite its beneficial effects, the intensive insulin therapy (IIT) has been a point related to much controversy, because it leads to a risk of hypoglycemia [8] which can be more dangerous than hyperglycemia due to BI [8,9]. Therefore, this review aims to investigate the animal models of extensive BI with IIT, in order to better understand the benefits and limitations of this therapy.

\footnotetext{
${ }^{*}$ Corresponding author: Quintana Hananiah Tardivo
} 


\section{Methods}

A computerized literature search was done in PubMed-Medline database. The keywords that we used were Burn, either Thermal Injury or Scald. Together another group of keywords related to IIT: Intensive Insulin Treatment or Therapy, Detemir, Glargine, Lantus, NPH, protamine, Iletin and Insulin. After that, we selected to read the complete paper in Portuguese, English and Spanish. Other languages were not considered. As an excluding criteria, the papers with euthanasia of animals for a minimum for 24 hours post injury, i.e. experimental models that received IIT at least 1 day or more. Thus, 14 papers were presented in Table 1, considering the percentage of TBSA scalding injury.

\section{Results}

\subsection{Systemic responses after extensive burn injury}

BI over $40 \%$ of body extension are considered extensive and result in the local and systemic responses [10]. The extensive BI are followed by long periods of stress, inflammation and hypermetabolism, characterized by increase of the hypermetabolic state such as glycolysis, proteolysis, lipolysis, glycogenolysis, and gluconeogenesis [6,11]. In addition, there is a significant increase in the energetic expenditure, which is not supplied by catabolic state during hypermetabolism [12,13], resulting in an imbalance of the use and the availability of the energy [10]. The hypermetabolic state elevates energy expenditure to maximum at 10 days after BI [14], remaining altered for two years post-burn in children [5].

Besides, several authors mention that immune dysfunction [15], acute IR, hyperglycemia [16], protein catabolism, muscle atrophy $[12,13,17]$, hepatocyte degeneration [18] and decreased bone mineral content [5] are characteristics of BI systemic response.

Severe BI also are associated to increased expression of pro-inflammatory cytokines such as tumor necrosis factor alpha (TNF- $\alpha$ ), interleukin (IL1-6) and cyclooxygenase [5,14,19]. These inflammatory mediators induce systemic inflammatory response syndrome (SIRS) that leads to hypermetabolism, hemodynamic alterations, and increased energetic expenditure. These alterations can result in infection and sepsis with high risk of multiple-organ failure and death [10].

Oxidation energy substrates in mitochondrial respiration produce excessive formation of reactive oxygen species resulting oxidative stress, which together with the increased level of inflammatory mediators, promote IR [20] or pseudodiabetes [21].

After 3 or 4 days of the BI, the dependent tissues of the insulin, such as skeletal muscle and fat, develop an IR [22] that persist for several weeks $[21,23]$. In addition, the cellular stresses caused by extensive BI also active neuroendocrine response that increase the release of hormones as catecholamine, glucagon and cortisol [6].

In normal condition, insulin signaling on skeletal muscles and fat occurs via insulin receptor/insulin receptor substrates/phosphatidylinositol 3-kinase/protein kinase B (IR/IRS/PI3K/Akt) and translocation of glucose transporter - 4 (GLUT-4) to membrane, allowing the entry of glucose for facilitated diffusion [24]. After extensive BI, there are changes in the receptor insulin signaling, more specifically in phosphorylation of IRS-1 resulting to decrease glucose uptake $[21,25]$.

The absence of glucose uptake adequate in the cell lead to increased plasmatic glucose and, consequently elevated rate of body glucose production. Thus, a hyperglycemia is a risk factor to burn patients, because it helps to keep the hypermetabolism [6]. These alterations leads to predisposition to complications, such as development of infections that complicate the rehabilitation and increase the mortality [16,26]. The Figure 1 schematizes the extensive BI responses, which involves from local consequences until systemic, creating cycle where the more injury extension, more extended responses. 


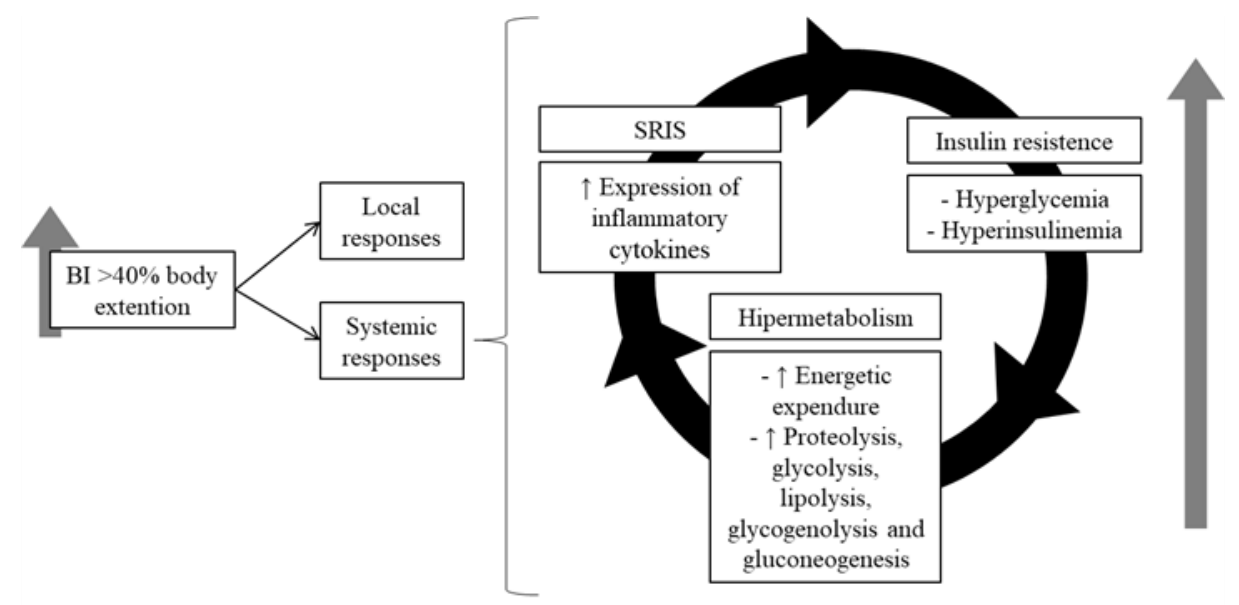

Figure 1 Extensive burn injury and systemic alterations cycle.

\subsection{Intensive insulin therapy after extensive burn injury}

For patients with extensive BI, glycemic control can be maintained by IIT [4,27-29]. This therapy has been used to control IR and hyperglycemia and reduce the inflammatory response [27], improve protein balance [30] and wound healing [31].

However, the glycemic control in patients that need intensive care can lead to hypoglycemic episodes $[8,11,32]$. Important to highlight that normal glycemic level in humans is considered to be between $80-110 \mathrm{mg} / \mathrm{dl}$ [33]. Patients with hypoglycemia (blood glucose $<60 \mathrm{mg} / \mathrm{dl}$ ) have many negative effects similar to hyperglycemia (blood glucose $>110$ $\mathrm{mg} / \mathrm{dl}$ ), for example, increased inflammatory and metabolic responses, frequent infections, tendency to multiple organ failure and rise in mortality [9].

Jeschke and collaborators [34] found that IIT for severely burned children maintained stable glucose levels and significantly improved insulin sensitivity. Effective glucose control attenuated a hypermetabolic response compared to patients with ineffective glucose control. However, sometimes glycemic control with insulin therapy resulted in these patients experiencing several episodes of hypoglycemia.

Fram et al. [35] demonstrated that children with burned total body surface area $\geq 40 \%$ who received IIT maintained daily blood glucose levels between $80-110 \mathrm{mg} / \mathrm{dl}$, but those children who received conventional insulin therapy maintained blood glucose levels $\geq 215 \mathrm{mg} / \mathrm{dl}$. The authors observed in burned children with control glucose levels $\leq 120$ $\mathrm{mg} / \mathrm{dl}$ improved insulin sensitivity, and decreased oxidative mitochondria and energy expenditure. Tuvdendorj et al. [31], in a study with patients $<18$ years with burned $\geq 30 \%$ total body surface area (TBSA) that received IIT and skin grafting, described there was an increase in the fractional synthesis rate of site wound protein compared to children that did not received any insulin treatment.

It is possible to observe some beneficial effects of intensive insulin therapy and effective glycemic control. However, the challenge related to preventing hypoglycemia episodes persists and needs more research [29]. Due to different glucose levels registered in studies and in numerous protocols related to appropriate insulin dosage, experimental models has been studied as a model of treatment in extensive burns.

Only few studies have proposed systemic therapies for extensive BI. Part of these were experimental studies that used food replacement therapies but hormone treatment are little explored. For this reason, the understanding of hormonal effects as a therapeutic option is an eminent challenge for advances in this field. Therefore, the main criteria for the present paper was to review the literature concerning IIT following scalding injury (SI) in animal models. 
Table 1 Studies that utilized insulin treatment in burn animal models for a minimum of 24 hours ( 1 day).

\begin{tabular}{|c|c|c|c|c|c|c|c|}
\hline Author & $\begin{array}{l}\text { TBSA } \\
(\%)\end{array}$ & $\begin{array}{l}\text { Insulin/acti } \\
\text { on }\end{array}$ & Via & Dosage & Period of IIT until euthanasia & $\begin{array}{l}\text { Results about glycemic } \\
\text { control }^{*}\end{array}$ & Other results of IIT about SI \\
\hline $\begin{array}{l}\text { Emanuele } \\
\text { et al., } 2007 \\
{[53]}\end{array}$ & $\begin{array}{l}13- \\
15 \%\end{array}$ & $\begin{array}{l}\text { Insulin } \\
\text { Glargine - } \\
\text { Long-acting }\end{array}$ & Subcutaneous & $\begin{array}{l}\text { Once a day, } \\
5 \mathrm{UI} / \mathrm{kg}\end{array}$ & Groups with IIT for 1,2 and 7 days & $\begin{array}{l}\mathrm{C}<\mathrm{SI}>\mathrm{SI}+\mathrm{I} \\
\text { Had difference between the } \\
\text { groups after IIT }\end{array}$ & $\begin{array}{l}\text { IIT decreased liver fatty } \\
\text { infiltration and alanine } \\
\text { aminotransferase blood levels }\end{array}$ \\
\hline $\begin{array}{l}\text { Solomon et } \\
\text { al., } 2000 \\
{[44]}\end{array}$ & $\begin{array}{l}15- \\
20 \%\end{array}$ & $\begin{array}{l}\text { Intermediate } \\
\text {-acting } \\
\text { insulin }\end{array}$ & Subcutaneous & $\begin{array}{l}\text { Twice a day (11- } \\
12 \mathrm{~h} \text { intervals), } \\
\text { dose was } \\
\text { gradually } \\
\text { increased }\end{array}$ & $\begin{array}{l}0.25 \mathrm{U} \text { (day } 1 \text { and } 2 \text { ), } 0.5 \mathrm{U} \text { (day } 3 \text { ), } \\
1.0 \mathrm{U} \text { (day } 4 \text { )/100g. Groups with } \\
\text { IIT for } 1 \text { and } 4 \text { days }\end{array}$ & $\begin{array}{l}\text { IIT did not induce long-term } \\
\text { hypoglycemia, in } 3 \mathrm{~h} \text { glycemia } \\
\text { returned to normal values. }\end{array}$ & $\begin{array}{l}\text { IIT suppressed of ubiquitin } \\
\text { conjugation to endogenous } \\
\text { proteins and cathepsin activities }\end{array}$ \\
\hline $\begin{array}{l}\text { Solomon et } \\
\text { al., } 2002 \\
{[45]}\end{array}$ & $\begin{array}{l}15- \\
20 \%\end{array}$ & $\begin{array}{l}\text { Intermediate } \\
\text {-acting } \\
\text { insulin }\end{array}$ & Subcutaneous & $\begin{array}{l}\text { Twice a day (11- } \\
12 \mathrm{~h} \text { intervals), } \\
\text { dose was } \\
\text { gradually } \\
\text { increased }\end{array}$ & $\begin{array}{l}0.25 \mathrm{U} \text { (day } 1 \text { and } 2 \text { ), } 0.5 \mathrm{U} \text { (day } 3 \text { ), } \\
1.0 \mathrm{U} \text { (day } 4 \text { )/100g. Groups with } \\
\text { IIT for } 4 \text { days }\end{array}$ & $\begin{array}{l}\text { IIT did not induce long-term } \\
\text { hypoglycemia, in } 3 \mathrm{~h} \text { glycemia } \\
\text { returned to normal values. }\end{array}$ & $\begin{array}{l}\text { IIT restored body weight by } \\
\text { reducing protein degradation } \\
\text { and regaining the intracellular } \\
\text { protein content in skeletal } \\
\text { muscle }\end{array}$ \\
\hline $\begin{array}{l}\text { Madibally } \\
\text { et al., } 2003 \\
{[15]}\end{array}$ & $\begin{array}{l}15- \\
20 \%\end{array}$ & $\begin{array}{l}\text { Intermediate } \\
\text {-acting } \\
\text { insulin }\end{array}$ & Subcutaneous & $\begin{array}{l}\text { Twice a day (11- } \\
12 \mathrm{~h} \text { intervals), } \\
\text { dose was } \\
\text { gradually } \\
\text { increased }\end{array}$ & $\begin{array}{l}0.25 \mathrm{U} \text { (day } 1 \text { and } 2 \text { ), } 0.5 \mathrm{U} \text { (day } 3 \text { ), } \\
1.0 \mathrm{U}(\text { day } 4 \text { ) } / 100 \mathrm{~g} \text {. Groups with } \\
\text { IIT for } 4 \text { and } 15 \text { days }\end{array}$ & $\begin{array}{l}\text { IIT did not induce long-term } \\
\text { hypoglycemia, in } 3 \text { h glycemia } \\
\text { returned to normal values. }\end{array}$ & $\begin{array}{l}\text { IIT decreased inflammatory cells } \\
\text { and increased vasodilation, } \\
\text { reepithelialization, collagen } \\
\text { deposition in wounds burn skin }\end{array}$ \\
\hline $\begin{array}{l}\text { Madihally } \\
\text { et al., } 2006 \\
{[46]}\end{array}$ & $\begin{array}{l}15- \\
20 \%\end{array}$ & $\begin{array}{l}\text { Intermediate } \\
\text {-acting } \\
\text { insulin }\end{array}$ & Oral & $\begin{array}{l}\text { Twice a day (11- } \\
12 \mathrm{~h} \text { intervals), } \\
\text { dose was } \\
\text { gradually } \\
\text { increased }\end{array}$ & $\begin{array}{l}\text { Insulin particles were loaded into } \\
\text { gelatin capsules for oral } \\
\text { administration. } 0.25 \mathrm{U} \text { (day 1), } \\
0.5 \mathrm{U} \text { (day } 2 \text { ), } 1.0 \mathrm{U} \text { (day } 3 \text { )/100g. } \\
\text { Groups with IIT for } 15 \text { days }\end{array}$ & $\begin{array}{l}\text { IIT did not induce long-term } \\
\text { hypoglycemia, in } 3 \mathrm{~h} \text { glycemia } \\
\text { returned to normal values. }\end{array}$ & $\begin{array}{l}\text { IIT improved the body weight } \\
\text { gain of burned rats and } \\
\text { accelerated the wound healing }\end{array}$ \\
\hline $\begin{array}{l}\text { Jeschke et } \\
\text { al., } \quad 2002 \\
{[38]}\end{array}$ & $30 \%$ & $\begin{array}{l}\text { Protamin } \\
\text { insulin - } \\
\text { Long-acting }\end{array}$ & Subcutaneous & $\begin{array}{l}\text { Once a day, } \\
5 \mathrm{UI} / \mathrm{kg}\end{array}$ & $\begin{array}{l}\text { Groups with IIT for } 1,2,5 \text { and } 7 \\
\text { days }\end{array}$ & $\begin{array}{l}\mathrm{C}<\mathrm{SI}>\mathrm{SI}+\mathrm{I} \\
\text { Had significant difference } \\
\text { between the groups after IIT }\end{array}$ & $\begin{array}{l}\text { IIT attenuated the inflammatory } \\
\text { response by decreasing the } \\
\text { proinflammatory and increasing } \\
\text { the anti-inflammatory cascade in } \\
\text { serum blood }\end{array}$ \\
\hline $\begin{array}{l}\text { Klein et al., } \\
2004 \text { [39] }\end{array}$ & $30 \%$ & $\begin{array}{l}\text { Protamin } \\
\text { insulin - } \\
\text { Long-acting }\end{array}$ & Subcutaneous & $\begin{array}{l}\text { Once a day, } \\
5 U I / k g\end{array}$ & $\begin{array}{l}\text { Groups with IIT for } 1,2,5 \text { and } 7 \\
\text { days }\end{array}$ & $\begin{array}{l}\text { SI }>\text { SI+I } \\
\text { Had significant difference } \\
\text { between the groups after IIT }\end{array}$ & $\begin{array}{l}\text { IIT decreased the expression of } \\
\text { pro-inflammatory cytokines } \\
\text { mRNA and apoptosis in the liver }\end{array}$ \\
\hline
\end{tabular}


Quintana HT et al. / World Journal of Advanced Research and Reviews, 2020, 07(02), 034-044

\begin{tabular}{|c|c|c|c|c|c|c|c|}
\hline $\begin{array}{l}\text { Zhang et } \\
\text { al., } 2011 \\
{[48]}\end{array}$ & $30 \%$ & - & Subcutaneous & $\begin{array}{l}\text { Once a day, } 3 \text { to } \\
5 \mathrm{UI} / \mathrm{kg}\end{array}$ & Groups with IIT for 24 hours & $\begin{array}{l}\mathrm{C} \cong \mathrm{SI}+\mathrm{I}<\mathrm{SI} \\
\mathrm{IIT} \text { did not induce } \\
\text { hypoglycemia. Had significant } \\
\text { difference between SI+I and SI } \\
\text { groups, for } 3,6,12 \text { and } 24 \mathrm{~h} \\
\text { after IIT }\end{array}$ & $\begin{array}{l}\text { IIT decreased pulmonary edema, } \\
\text { hemorrhage, inflammatory cell } \\
\text { infiltration and apoptosis }\end{array}$ \\
\hline $\begin{array}{l}\text { Wang et } \\
\text { al., } 2012 \\
{[41]}\end{array}$ & $30 \%$ & $\begin{array}{l}\text { Insulin } \\
\text { Glargine - } \\
\text { Long-acting }\end{array}$ & $\begin{array}{l}\text { Intraperitoneal } \\
\text { ly }\end{array}$ & $\begin{array}{l}\text { Once a day, } \\
\text { glucose-insulin } \\
\left(70 \mathrm{UI}^{-1}\right) \text { and } \\
\text { insulin } 30 \mathrm{UI}^{-1}\end{array}$ & Groups with IIT for 1,3 and 5 days & $\begin{array}{l}\mathrm{SI}+\mathrm{I}<\mathrm{SI} \cong \mathrm{SI}+\mathrm{GI}^{* *} \\
\text { Had significant difference } \\
\text { between the groups after IIT }\end{array}$ & $\begin{array}{l}\text { IIT attenuated the inflammation } \\
\text { and necrosis on the intestinal } \\
\text { epithelium }\end{array}$ \\
\hline $\begin{array}{l}\text { Han et al., } \\
2014 \text { [49] }\end{array}$ & $30 \%$ & - & Subcutaneous & $\begin{array}{l}\text { Once a day, } 3 \text { to } \\
5 \mathrm{UI} / \mathrm{kg}\end{array}$ & Groups with IIT for 24 hours & $\begin{array}{l}\mathrm{C} \cong \mathrm{SI}+\mathrm{I}<\mathrm{SI} \\
\mathrm{IIT} \text { did not induce } \\
\text { hypoglycemia. Had significant } \\
\text { difference between SI+I and SI } \\
\text { groups, for } 3,6,12 \text { and } 24 \mathrm{~h} \\
\text { after IIT }\end{array}$ & $\begin{array}{l}\text { IIT attenuated the increase of } \\
\text { pulmonary endothelial } \\
\text { permeability and decreased } \\
\text { pulmonary edema, hemorrhage, } \\
\text { inflammatory cell infiltration } \\
\text { and apoptosis }\end{array}$ \\
\hline $\begin{array}{l}\text { Przkora et } \\
\text { al., } 2007 \\
{[47]}\end{array}$ & $35 \%$ & $\begin{array}{l}\text { Intermediate } \\
\text {-acting } \\
\text { insulin }\end{array}$ & $\begin{array}{l}\text { Intraperitoneal } \\
\text { ly }\end{array}$ & $\begin{array}{l}\text { Once a day, } \\
5 \mathrm{UI} / \mathrm{Kg}\end{array}$ & Group with IIT for 5 days & $\mathrm{SI}+\mathrm{I} \cong \mathrm{SI}$ & $\begin{array}{l}\text { IIT decreased pro-inflammatory } \\
\text { cytokines and increased anti- } \\
\text { inflammatory cytokines in } \\
\text { serum blood, increasing survival } \\
\text { to Pseudomonas aeruginosa }\end{array}$ \\
\hline $\begin{array}{l}\text { Pidcoke et } \\
\text { al., } 2014 \\
{[40]}\end{array}$ & $40 \%$ & $\begin{array}{l}\text { Protamin } \\
\text { zinc insulin - } \\
\text { Long-acting }\end{array}$ & Subcutaneous & $\begin{array}{l}\text { Once a day, } \\
5 \mathrm{UI} / \mathrm{Kg}\end{array}$ & Group with IIT for 12 days & $\begin{array}{l}\text { Glucose tolerance test } \\
\mathrm{C} \cong \mathrm{SI}+\mathrm{I}<\mathrm{SI} \\
\text { Had significant difference } \\
\text { between the groups }\end{array}$ & $\begin{array}{l}\text { IIT attenuated the } \\
\text { hypermetabolic response and } \\
\text { atrophy muscle }\end{array}$ \\
\hline $\begin{array}{l}\text { Gauglitz et } \\
\text { al., } \quad 2010 \\
{[42]}\end{array}$ & $60 \%$ & $\begin{array}{l}\text { Insulin } \\
\text { Glargine } \\
\text { Long-acting }\end{array}$ & Subcutaneous & $\begin{array}{l}\text { Once a day, dose } \\
\text { was gradually } \\
\text { increased }\end{array}$ & $\begin{array}{l}1 \mathrm{U}(\text { day } 1), 2,5 \mathrm{U} \text { (day 2), } 5 \mathrm{U} \text { (day } \\
\text { 3)/100g. Groups with IIT for } 28 \\
\text { days }\end{array}$ & $\begin{array}{l}\mathrm{C} \cong \mathrm{SI}+\mathrm{I}<\mathrm{SI} \\
\text { Had significant difference } \\
\text { between SI+I and SI groups, } \\
\text { for } 3 \text { and } 6 \mathrm{~h} \text { after IIT }\end{array}$ & $\begin{array}{l}\text { IIT attenuated acute pro- } \\
\text { inflammatory response, } \\
\text { increasing survival to } \\
\text { Pseudomonas aeruginosa burn } \\
\text { wound infection }\end{array}$ \\
\hline $\begin{array}{l}\text { Jeschke et } \\
\text { al., } 2010 \\
{[43]}\end{array}$ & $60 \%$ & $\begin{array}{l}\text { Insulin } \\
\text { Glargine } \\
\text { Long-acting }\end{array}$ & Subcutaneous & $\begin{array}{l}\text { Once a day, } 2.5 \\
\text { UI/kg }\end{array}$ & Group with IIT for 1 and 2 days & $\begin{array}{l}\mathrm{C} \cong \mathrm{SI}+\mathrm{I}<\mathrm{SI} \\
\text { Had significant difference } \\
\text { between the groups }\end{array}$ & $\begin{array}{l}\text { IIT decreases hepatic apoptosis, } \\
\text { mitochondrial damage, and } \\
\text { increases albumin production }\end{array}$ \\
\hline
\end{tabular}

*To facilitate the understanding of the reader, we will call here the groups of the revised papers: Control for sham animals without IIT and without SI; SI for the injured group without IIT; and SI+I for injured and treated groups.

${ }^{* *}$ Only this paper presented a SI group with treatment mixed insulin (IIT) and glucose (SI+GI) 


\subsection{Intensive insulin therapy in experimental models of extensive burn injury}

The extent of the SI varied greatly between articles (13-60\%). SI of 30\% TBSA or more was considered extensive and resulted in hormonal and metabolic, local and systemic responses $[4,5,10,36]$. However, all articles presented in Table 1 indicated several systemic responses in many body organs or systems, independent of the TBSA scald burn.

The periods of IIT in the papers studied changed considerably. Some focused on short-term treatments between 1 and 5 days, regardless of the type of insulin used or daily doses defined. However, only two articles focused on 7-day treatments to evaluate the long term infiltration of adipose tissue into the liver [37] and the decrease of several proinflammatory markers [38]. Finally, just one paper lasted 15 days, until the complete regeneration of the animals' skin wounds.

Seven of the fourteen papers (Table 1) mentioned the use of long-acting insulin for IIT; three used protamine insulin [38-40] and four used glargine insulin [37, 41-43]. Five other papers used intermediate-acting insulin [15,44-47]. Two papers $[48,49]$ did not report the period of insulin action, but reported that the insulin dose and glucose blood level were controlled daily. Just one paper used a mixture of $5 \mathrm{IU} / \mathrm{kg}$ insulin injected together with glucose, once a day [41], in order to avoid hypoglycemia in treated animals.

Insulin glargine and protamine are long-acting types of insulin that reach a plateau of biological action, promoting a basal coverage throughout 24 hours [50,51]. Studies with humans showed that patients treated with glargine, longacting insulin, had significantly lower hypoglycemia events compared to patients that use intermediate-acting insulin, such as neutral protamine hagedorn insulin (NPH) [52].

Regarding the dosage of IIT, the groups that applied insulin with a gradual dosage increase from 0.5IU to 1.0IU per 100 $\mathrm{g}$ of animal body weight, used two applications per day because they used intermediate-acting insulin that has a halflife of between 11 and 12 hours [15, 44-46]. The similar dosage was applied in the groups that received long-acting insulin (2.5 to $5 \mathrm{IU} / \mathrm{kg}$ ), but only a daily dosage was applied [38-40, 43, 48, 49, 53]. Just a paper utilized intermediateacting insulin in a daily dosage [47]. Related to the insulin routes of administration form, only Medihally et al. [46] used oral insulin, the other authors applied intraperitoneal or subcutaneous injections.

Regarding the insulin action, the number of daily injections was once when the authors used a long-acting insulin, and two for intermediate-acting insulin. This latter insulin type required an increase of animal manipulation and consequently this animal receive more stress than the animal that received double subcutaneous injections, except for assays presented by Przkora et al. [47] who injected the intermediate-acting insulin once a day. Then, a long-acting insulin therapy would minimize the stress and manipulation of animals that already have the injury burn stress.

Among the factors that provided influence in experimental models with IIT, the most important was the glycemic control. In experimental models with extensive SI, the rats or mice had an acute state of hyperglycemia that was maintained in few days after SI. Hyperglycemia and hypermetabolism cause metabolic stress, which is the most significant response to SI [6, 42], as result of increased hepatic gluconeogenesis [6].

In the surveyed papers, the glycemic control was carried out daily in all animals that received the treatment because of IIT and the glycemic changes promoted by extensive SI. Thus, the blood glucose level evaluations showed that the animals' glycemia returned to normal values approximately 3 hours after IIT, indicating that IIT does not induce longterm hypoglycemia [44, 46]. However, in studies that administered a gradually increasing IIT dose, the animals had hypoglycemia in the first hour after insulin administration $(1 \mathrm{U} / 100 \mathrm{~g})[44,45]$. That indicated that the dosage was too high for these animals. Interestingly, just one study used a fourth group for comparing parameters of glycemia and insulinemia control. The sham group received ITT the same as the SI group [45].

For studies that use hormone therapy with insulin, an important consideration is regard to glycemic control because the risk of hypoglycemia $[7,54]$. Therefore, all the reviewed papers focused on glycemic control of the animals, one hour or a few days after starting IIT, or at the end of IIT.

In the initial phase of the response to the extensive SI, a hyperglycemic state occurs, followed by a subsequent phase where there was predominance of protein hypermetabolism [6]. Thus, some studies consider that insulin did not induce long periods of hypoglycemia after IIT, regardless of the dosage injected. Approximately 3 hours after application, the animals were euglycemic $[15,44-46]$. So, IIT with exogenous insulin has been shown capable of reducing hyperglycemia, together with the level of IR [54]. In the surveyed papers, the animals submitted to extensive SI showed 
hyperglycemia in the evaluation of glycemic control, compared to the Control and SI+IIT groups. Therefore, insulin was able to revert the hyperglycemia after SI, regardless of the dosage administered, number of daily applications, type of insulin (intermediate or long action) and, number of days of treatment [38,39,41,43,47-49,53,55].

In addition to the glycemic control results, the IIT also was able to promote systemic responses linked to the consequences of extensive SI that the animals received. Other effects of IIT were observed in wound healing, several organs, such as liver, skeletal muscle, lung and intestine, and investigated in inflammatory cascades in blood.

IIT induced wound healing. Four days after SI, in the acute phase, a histologic evaluation of SI wounds showed decrease of inflammatory cells, and increase in vasodilation and collagen deposition. In a late phase, after 15 days, IIT increased re-epithelization when compared to SI untreated group [15]. The acceleration of wound healing in animals that received IIT also promoted body weight gain [46].

Regarding the liver, IIT decreased hepatic apoptosis, mitochondrial damage, and increased albumin production in acute phase, at 24 and 48 hours, after SI [43]. Seven days after SI, in the late phase, IIT decreased blood levels of alanine aminotransferase enzyme, related to damage to hepatocytes membrane. In addition, it prevented an increase of microvesicular steatosis [53], and decreased the mRNA expression of some pro-inflammatory cytokines [39].

IIT markedly attenuated acute lung injuries. In histologic analyses of lungs, a decrease has been observed in pulmonary edema, haemorrhages, inflammatory cell infiltration and cell apoptosis after 12 hours [48,49] and 24 hours [48], besides attenuating the increase of pulmonary endothelial permeability induced by BI [49]. Finally, Wang et al. [41] investigated the effects of SI on the intestine and used IIT together with glucose. After 2 days of treatment, the animals showed a decrease in infiltration of inflammatory cells and necrosis sites in intestinal epithelium compared to the untreated SI group.

IIT has been found to suppress the ubiquitin conjugation of endogenous proteins in muscle, and to decrease some cathepsin activities after 1 and 4 days [44], and also to restore body weight by reducing accelerated protein degradation after 4 days [45]. In animals that have been submitted to SI and had their limbs immobilized, IIT attenuated the muscle loss in soleus and gastrocnemius muscles, the hypermetabolic response and atrophy. It also increased glucose clearance and normalized circadian-metabolic protein [40].

Regarding of SIRS the extensive SI, IIT was also capable of reducing the inflammation after 1 to 7 days, by decreasing several pro-inflammatory cytokines (TNF, IL-1 and IL-6), and increasing anti-inflammatory cytokines (IL-2, IL-4 and IL10) in blood serum [45]. The application of IIT together with glucose after 1 to 5 days decreased the IL-10 and TNF expression [41]. One of the most common bacteria that cause lethal infections in burn patients is Pseudomonas Aeruginosa. In animals that received an injection of these bacteria after SI, IIT was capable of decreasing several proinflammatory cytokines and increasing several anti-inflammatory cytokines in serum blood in these animals [47]. IIT also improved the survival of the animals following infection of SI wounds with Pseudomonas Aeruginosa [42]. Summering IIT has been shown as effective therapy for the care of systemic effects post extensive BI.

The variations of treatment and difficulties related to obtaining invasive analysis of tissues in humans and appropriate glucose levels without hypoglycemic episodes during the treatment, justify the importance of experimental study in this area. In experimental models, ITT has been shown as capable of improving glycemic control and attenuate numerous disturbs caused by SI. However, it is important to highlight that the extension of lesion, periods of IIT, type and dosage of insulin varied considerably. Thus, Figure 2 presents the benefits and limitations of the ITT of extensive SI models in a schematic form on a scale. In addition, there are difficulties to establish the ideal glucose level to consider normoglycemic state of varieties of species utilized. The main challenge consists in establish the gold standard of glucose level associated to the attenuation of as much as possible systemic effects of SI. So more studies about results of treatments in humans and standardized experimental models are necessary to the best knowledge of insulin treatment post extensive burn. 


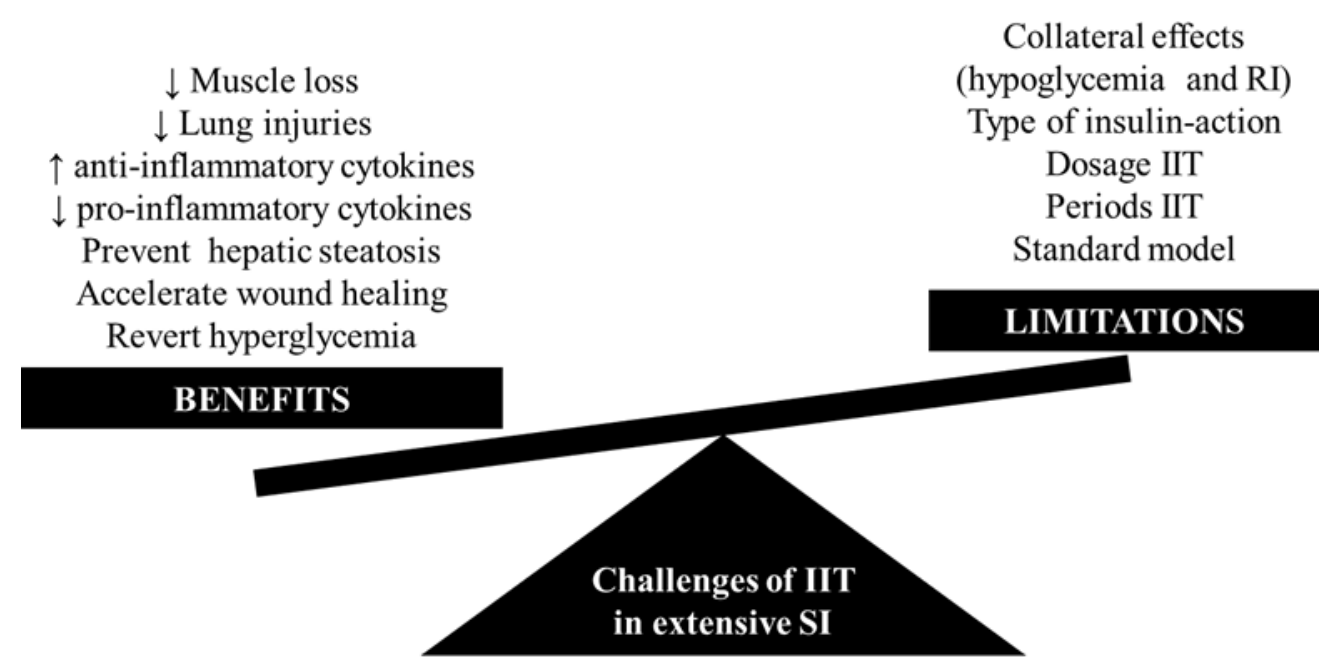

Figure 2 Benefits and limitations of ITT of extensive SI models. Note that although there are limitations based on burn standard or insulin administration, numerous benefits of systemic effects attenuation post SI are considered.

\section{Conclusion}

It concludes, although there are limitations related to burn standard or insulin administration, the systemic benefits effects of ITT outweigh limitations.

\section{Compliance with ethical standards}

\section{Acknowledgments}

We would like to thank anonymous reviewers for constructive comments on the manuscript.

\section{Disclosure of conflict of interest}

The authors declare no conflict of interest. And all authors have made substantial contributions to the article.

\section{References}

[1] World Health Organization. Burns. Media Centre (2018).

[2] Ministério da Saúde. Informações epidemiológicas e morbidade. Brasil Datasus Informações de Saúde 2018.

[3] Gawryszewski VP, Bernal RTI, Silva NN da, Morais Neto OL de, Silva MMA da, Mascarenhas MDM, Sá NN, Monteiro RA and Malta DC. (2012). Public hospital emergency department visits due to burns in Brazil, 2009. Cadernos de Saúde Pública, 28(4), 629-640.

[4] Jeschke MG, Mlcak RP, Finnerty CC, Norbury WB, Gauglitz GG, Kulp GA and Herndon DN. (2007). Burn size determines the inflammatory and hypermetabolic response. Critical Care, 11, 1-11.

[5] Jeschke MG, Gauglitz GG, Kulp GA, Finnerty CC, Williams FN, Kraft R, Suman OE, Mlcak RP and Herndon DN. (2011). Long-term persistance of the pathophysiologic response to severe burn injury. PLoS ONE, 6(7), e21245.

[6] Atiyeh BS, Gunn SWA and Dibo SA. (2008). Metabolic implications of severe burn injuries and their management: A systematic review of the literature. World Journal of Surgery, 32(8), 1857-1869.

[7] Rojas Y, Finnerty CC, Radhakrishnan RS and Herndon DN. (2012) Burns: an update on current pharmacotherapy. Expert Opinion on Pharmacotherapy, 13(17), 2485-2494. 
[8] Finfer S, Liu B, Chittock DR, Norton R, Myburgh JA, McArthur C, Mitchell I, Foster D, Dhingra V, Henderson WR, Ronco JJ, Bellomo R, Cook D, McDonald E, Dodek P, Hébert PC, Heyland DK and Robinson BG. (2012). Hypoglycemia and Risk of Death in Critically Ill Patients. New England Journal of Medicine 367(12), 1108-1118.

[9] Jeschke MG, Pinto R, Herndon DN, Finnerty CC and Kraft R. (2014). Hypoglycemia is associated with increased postburn morbidity and mortality in pediatric patients. Critical Care Medicine, 42(5), 1221-1231.

[10] Krishnamoorthy V, Ramaiah R and Bhananker S. (2012). Pediatric burn injuries. International Journal of Critical Illness and Injury Science, 2(3), 128-134.

[11] Jeschke MG. (2009). The Hepatic Response to Thermal Injury: Is the Liver Important for Postburn Outcomes? 15(9-10), 337-351.

[12] De Oliveira F, Bevilacqua LR, Anaruma AC, Boldrini SC and Liberti EA. (2010). Trauma Morphological changes in distant muscle fibers following thermal injury in Wistar rats, 25(6), 525-528.

[13] Quintana HT, Bortolin JA, da Silva NT, Ribeiro FAP, Liberti EA, Ribeiro DA and De Oliveira F (2014). Temporal study following burn injury in young rats is associated with skeletal muscle atrophy, inflammation and altered myogenic regulatory factors. Inflammation Research, 64(1), 53-62.

[14] Hill M and Goldspink G. (2003). Expression and Splicing of the Insulin-Like Growth Factor Gene in Rodent Muscle is Associated with Muscle Satellite (stem) Cell Activation following Local Tissue Damage. The Journal of Physiology, 549(Pt 2), 409-418.

[15] Madibally S V, Solomon V, Mitchell RN, De Water L Van, Yarmush ML and Toner M. (2003). Influence of Insulin Therapy on Burn Wound Healing in Rats. Journal Surgery Research, 109(2), 92-100.

[16] Holm C, Hörbrand F, Mayr M, Von Donnersmarck GH and Mühlbauer W. (2004). Acute hyperglycaemia following thermal injury: Friend or foe? Resuscitation, 60(1), 71-77.

[17] Da Silva NT, Quintana HT, Bortolin JA, Ribeiro DA and De Oliveira F. (2015). Burn Injury Induces Skeletal Muscle Degeneration, Inflammatory Host Response, and Oxidative Stress in Wistar Rats. Journal of Burn Care \& Research, 36(3), 428-433.

[18] Bortolin JA, Quintana HT, Tomé TC, Ribeiro FAP, Ribeiro DA and De Oliveira F. (2016). Burn injury induces histopathological changes and cell proliferation in liver of rats. World Journal of Hepatology, 8(6), 322-330.

[19] Gauglitz GG, Song J, Herndon DN, Finnerty CC, Boehning D, Barral JM and Jeschke MG. (2008). Characterization of the inflammatory response during acute and post-acute phases after severe burn. Shock, 30(5), 503-507.

[20] Eriksson JW. (2007). Metabolic stress in insulin's target cells leads to ROS accumulation - A hypothetical common pathway causing insulin resistance. FEBS Letters, 581(19), 3734-3742.

[21] Ikezu T, Okamoto T, Yonezawa K, Tompkins RG and Martyn JAJ. (1997). Analysis of thermal injury-induced insulin resistance in rodents. Implication of postreceptor mechanisms. Journal of Biological Chemistry, 272(40), 25289-25295.

[22] Chen XL, Xia ZF, Ben DF and Duo W. (2011). MTOR partly mediates insulin resistance by phosphorylation of insulin receptor substrate-1 on serine307residues after burn. Burns, 37(1), 86-93.

[23] Pidcoke HF, Salinas J, Wanek SM, Concannon M, Loo F, Wirfel KL, Holcomb JB, Wolf SE and Wade CE. (2007). Patterns of exogenous insulin requirement reflect insulin sensitivity changes in trauma. American Journal of Surgery, 194(6), 798-803.

[24] Pauli JR, Cintra DE, Souza CT and Ropelle ER. (2009). N New mechanisms by which physical exercise improves insulin resistance in the skeletal muscle. Arquivos Brasileiros de Endocrinologia \& Metabologia, 53(4), 399-408.

[25] Xin-Long C, Zhao-Fan X, Dao-Feng B, Jian-Guang T and Duo W. (2007). Insulin resistance following thermal injury: An animal study. Burns, 33(4), 480-483.

[26] Mann EA, Mora AG, Pidcoke HF, Wolf SE and Wade CE. (2009). Glycemic control in the burn intensive care unit: Focus on the role of anemia in glucose measurement. Journal of Diabetes Science and Technology, 3(6), 13191329.

[27] Jeschke MG, Boehning DF, Finnerty CC and Herndon DN. (2007). Effect of insulin on the inflammatory and acute phase response after burn injury. Critical Care Medicine, 35(9 Suppl), 519-523.

[28] Stoecklin P, Delodder F, Pantet $O$ and Berger MM. (2016). Moderate glycemic control safe in critically ill adult burn patients: A 15 year cohort study. Burns, 42(1), 63-70. 
[29] Lorente JA and Amaya-Villar R. (2016). Update in the management of critically ill burned patients. Medicina Intensiva, 40(1), 46-48.

[30] Ferrando AA, Chinkes DL, Wolf SE, Matin S, Herndon DN and Wolfe RR. (1999). A submaximal dose of insulin promotes net skeletal muscle protein synthesis in patients with severe burns. Annals of Surgery, 229(1), 11-18.

[31] Tuvdendorj D, Zhang XJ, Chinkes DL, Aarsland A, Kulp GA, Jeschke MG and Herndon DN. (2011). Intensive insulin treatment increases donor site wound protein synthesis in burn patients. Surgery, 149(4), 512-518.

[32] Jeschke MG, Kulp GA, Kraft R, Finnerty CC, Mlcak R, Lee JO and Herndon DN. (2010). Intensive insulin therapy in severely burned pediatric patients: A Prospective randomized trial. American Journal of Respiratory and Critical Care Medicine, 182(3), 351-359.

[33] Van den Berghe G, Wouters P, Weekers F, Verwaest C, Bruyninckx F, Schetz M, Vlasselaers D, Ferdinande P, Lauwers P and Bouillon R. (2001). Intensive Insulin Therapy in Critically Ill Patients. New England Journal of Medicine, 345(19), 1359-1367.

[34] Jeschke MG, Kraft R, Emdad F, Gabriela A, Williams FN and Herndon DN. (2013). Glucose control in severely thermally injured pediatric patients : what glucose range should be the target? Annals of Surgery, 252(3), 521527.

[35] Fram RY, Cree MG, Wolfe RR, Mlcak RP, Qian T, Chinkes DL and Herndon DN. (2010). Intensive insulin therapy improves insulin sensitivity and mitochondrial function in severely burned children. Critical Care Medicine, 38(6), 1475-1483.

[36] Jeschke MG, Finnerty CC, Herndon DN, Song J, Boehning D, Tompkins RG, Baker HV and Gauglitz GG. (2012). Severe Injury Is Associated With Insulin Resistance, Endoplasmic Reticulum Stress Response, and Unfolded Protein Response. Annals of Surgery, 255(2), 370-378.

[37] Emanuele NV, Emanuele MA, Morgan MO, Sulo D, Yong S, Kovacs EJ, Himes RD and Callaci JJ. (2009). Ethanol potentiates the acute fatty infiltration of liver caused by burn injury: Prevention by insulin treatment. Journal of Burn Care and Research, 30 (3), 482-488.

[38] Jeschke MG, Einspanier R, Klein D and Jauch KW. (2002). Insulin attenuates the systemic inflammatory response to thermal trauma. Molecular Medicine, 8(8), 443-450.

[39] Klein D, Schubert T, Horch RE, Jauch KW and Jeschke MG. (2004). Insulin treatment improves hepatic morphology and function through modulation of hepatic signals after severe trauma. Annals of Surgery, 240(2), 340-349.

[40] Pidcoke HF, Baer LA, Wu X, Wolf SE, Aden JK and Wade CE. (2014). Insulin effects on glucose tolerance, hypermetabolic response, and circadian-metabolic protein expression in a rat burn and disuse model. AJP: Regulatory, Integrative and Comparative Physiology, 307(1), R1-R10.

[41] Wang Z, Liu L, Hu T, Lei W, Wan F, Zhang P, Wang Z, Xu J, Zhu H, Zhu Z, Yang Y, Hu X, Xu L and Wang S. (2012). Protective effect of glucose-insulin-potassium (GIK) on intestinal tissues after severe burn in experimental rats. Burns, 38(6), 846-854.

[42] Gauglitz GG, Toliver-Kinsky TE, Williams FN, Song J, Cui W, Herndon DN and Jeschke MG. (2010). Insulin increases resistance to burn wound infection-associated sepsis. Critical Care Medicine, 38(1), 202-208.

[43] Jeschke MG, Kraft R, Song J, Gauglitz GG, Cox RA, Brooks NC, Finnerty CC, Kulp GA, Herndon DN and Boehning D. (2011). Insulin protects against hepatic damage postburn. Molecular Medicine, 17(5-6), 516-522.

[44] Solomon V, Madihally S, Yarmush M and Toner M. (2000). Insulin suppresses the increased activities of lysosomal cathepsins and ubiquitin conjugation system in burn-injured rats. Journal of Surgical Research, 93(1), 120-126.

[45] Solomon V, Madihally S, Mitchell RN, Yarmush M and Toner M. (2002). Antiproteolytic action of insulin in burninjured rats. Journal of Surgical Research, 105(2), 234-242.

[46] Madihally S V., Pantelogianis A and Toner M. (2006). Antiproteolytic Action of Orally Delivered Insulin Using pHResponsive Hydrogels in a Rat Burn Model. Journal of Surgical Research, 135(1), 187-194.

[47] Przkora R, Herndon DN, Finnerty CC and Jeschke MG. (2007). Insulin attenuates the cytokine response in a burn wound infection model. Shock, 27(2), 205-208.

[48] Zhang WF, Zhu XX, Hu DH, Xu CF, Wang YC and Lv GF. (2011). Intensive Insulin Treatment Attenuates BurnInitiated Acute Lung Injury in Rats: Role of the Protective Endothelium Journal Burn Care Research, 32(3), e51e58. 
[49] Han JT, Zhang WF, Wang YC, Cai WX, Lv GF and Hu DH. (2014). Insulin protects against damage to pulmonary endothelial tight junctions after thermal injury: Relationship with zonula occludens-1, F-actin, and AKT activity. Wound Repair and Regeneration, 22(1), 77-84.

[50] Heinemann L, Linkeschova R, Rave K, Hompesch B, Sedlak M and Heise T. (2000). Time-action profile of the longacting insulin analog insulin glargine (HOE901) in comparison with those of NPH insulin and placebo. Diabetes Care, 23(5), 644-649.

[51] Jensen MG, Hansen M, Brock B and Rungby J. (2010). Differences between long-acting insulins for the treatment of type 2 diabetes. Expert Opinion on Pharmacotherapy, 11(12), 2027-2035.

[52] Bullano MF, Al-Zakwani IS, Fisher MD, Menditto L and Willey VJ. (2005). Differences in hypoglycemia event rates and associated cost-consequence in patients initiated on long-acting and intermediate-acting insulin products. Current Medical Research and Opinion, 21(2), 291-298.

[53] Emanuele MA, Emanuele N V, Gamelli RL, Kovacs EJ and LaPaglia N. (2007). Effects of insulin on hepatic inflammation induced by ethanol and burn injury in a murine model of critical illness. Journal of Burn Care \& Research: Official Publication of the American Burn Association, 28(3), 490-499.

[54] Rousseau AF, Losser MR, Ichai C and Berger MM. (2013). ESPEN endorsed recommendations: Nutritional therapy in major burns. Clinical Nutrition, 32(4), 497-502.

[55] Jeschke MG, Kraft R, Emdad F, Kulp GA, Williams FN and Herndon DN. (2010). Glucose control in severely thermally injured pediatric patients: what glucose range should be the target? Annals of Surgery, 252(3), 521527.

\section{How to cite this article}

Quintana HT, Baptista VIA, Lazzarin MC and De Oliveira F. (2020). Challenges of the intensive insulin therapy in experimental models of extensive burn injury. World Journal of Advanced Research and Reviews, 7(2), 34-44. 